\title{
PENGARUH UKURAN PERUSAHAAN, JENIS OPINI AUDITOR, UKURAN KAP DAN AUDIT TENURE TERHADAP AUDIT DELAY
}

\author{
Dea Annisa \\ Universitas Esa Unggul \\ Email: deaannisaassa@gmail.com
}

\begin{abstract}
This study aimed to assess the effect of firm size, type of auditor's opinion, the audit firm size and the audit tenure on the audit delay listed on the Indonesia Stock Exchange period 2010 - 2014. This study used a sample of 90 companies manufacturing, analysis techniquesused is multiple regression with SPSS 20.

The results showed: (1) size of company, type of auditor's opinion, firm size and audit tenure simultaneous positive effect on audit delay, (2) the size of the company does not have negative effect the audit delay, (3) the type of auditor's opinion has negative effect to the audit delay, (4) the size of the firm does not have negative effect the audit delay, (5) audit tenure has negative affect to the audit delay. The study's findings indicate that type of auditor's opinion negatively affect audit delay with significance 0,002.
\end{abstract}

Keywords: audit delay, company size, type of auditor's opinion, the size of KAP, audit tenure.

\begin{abstract}
Abstrak
Penelitian ini bertujuan untuk menilai pengaruh ukuran perusahaan, jenis opini auditor, ukuran perusahaan audit dan audit tenure pada audit delay yang terdaftar di Bursa Efek Indonesia periode 2010 - 2014. Penelitian ini menggunakan sampel 90 perusahaan manufaktur, analisis Teknik yang digunakan adalah regresi berganda dengan SPSS 20.

terhadap audit delay, (3) jenis Opini auditor berpengaruh negatif terhadap audit delay, (4) ukuran perusahaan tidak berpengaruh negatif terhadap audit delay, (5) audit tenure berpengaruh negatif terhadap audit delay. Temuan penelitian menunjukkan bahwa jenis opini auditor berpengaruh negatif terhadap audit delay dengan signifikansi 0,002
\end{abstract}

Kata kunci: audit delay, ukuran perusahaan, jenis opini auditor, ukuran KAP, audit tenure. 


\section{PENDAHULUAN}

Laporan keuangan merupakan salah satu informasi yang penting untuk menggambil keputusan bagi banyak pihak. Pendapat auditor atas laporan keuangan akan memberikan keyakinan bahwa laporan keuangan tersebut dapat dipercaya kepada pemakainya. Perusahaan yang terdaftar di Bursa Efek Indonesia (BEI) wajib melaporkan laporan auditornya ke BEI secara tepat waktu agar informasi yang diperoleh oleh pihak yang membutuhkan laporan keuangan yang handal, relevan, mudah dipahami dan diperbandingkan.

Terkait relevansinya maka informasi yang terkandung dalam laporan keuangan akan sangat berguna apabila disajikan secara akurat dan tepat waktu. Ketepatan waktu berarti memiliki informasi yang tersedia untuk pengambil keputusan dalam waktu yang akan mampu mempengaruhi keputusan mereka. Umumnya semakin terlambat (lama) informasi maka informasi tersebut kurang berguna. (Astika,2010). Terjadinya penundaan yang tidak semestinya membuat informasi yang dihasilkan akan kehilangan relevansinya (Harahap, 2011). Seperti halnya laporan keuangan yang telah diaudit, apabila terlambat dalam menerbitkan tidak hanya berdampak pada kegunaan informasi tetapi juga relevansi dan reabilitasnya (Ahmed, 2010).Pengungkapan yang tertunda terhadap pendapat auditor yang benar dari informasi keuangan yang disusun oleh manajemen memperburuk asimetri informasi dan meningkatkan ketidakpastian dalam keputusan investasi (Nor et al, 2010). Keterlambatan laporan audit juga dapat membuat investor kehilangan kepercayaan dalam laporan yang akan disajikan (Ilaboya, 2014).

Berdasarkan catatan Bursa Efek Indonesia pada tahun 2010 jumlah perusahaan yang terlambat menyampaikan laporan keuangan hanya sebesar 59 perusahaan, kemudian pada tahun 2011 meningkat sebesar 92 perusahaan, pada tahun 2012 terdapat kenaikan signifikan yaitu sebesar 161 perusahaan yang terlambat menyampaikan laporan keuangan. Selanjutnya pada tahun 2013 mengalami sedikit penurunan yakni sebesar 141 perusahaan yang terlambat, namun kembali naik pada tahun 2014 terdapat 146 perusahaan yang terlambat menyampaikan laporan keuangan. Dengan masih ditemukannya audit delay di beberapa perusahaan yang terdaftar di BEI, penulis memandang perlu untuk meneliti kembali faktor-faktor yang mempengaruhi audit delay.

Berdasarkan ketentuan dari Bapepam-LK seluruh perusahaan yang terdaftar dalam pasar modal diwajibkan menyampaikan laporan keuangan secara berkala kepada Bapepam-LK serta mengumumkannya kepada publik. Perusahaan apabila terlambat dalam menyampaikan laporan, maka perusahaan tersebut akan dikenakan sanksi administratif sesuai dengan ketentuan yang telah ditetapkan dalam undang-undang. Tahun 2006 Bapepam-LK mengeluarkan peraturan No.Kep-06/BL/2006 mengenai penyampaian laporan keuangan, setelah itu untuk penyempurnaan peraturan sebelumnya, pada tanggal 5 Juli 2011 Bapepam-LK kembali menerbitkan peraturan No. X.K.2 Lampiran Keputusan Ketua Bapepam LK No.Kep-346/BL/2011 mengenai Penyampaian Laporan Keuangan Berkala Emiten dan Perusahaan Publik. Peraturan ini menyatakan bahwa laporan keuangan tahunan wajib disertai laporan akuntan dalam rangka audit atas laporan 
keuangan, dan wajib disampaikan kepada Bapepam-LK serta diumumkan kepada masyarakat paling lambat pada akhir bulan ketiga setelah tanggal laporan keuangan tahunan perusahaan. Bapepam-LK mengharuskan perusahaan publik melaporkan laporan keuangan yang telah diaudit dalam 60 sampai 90 hari setelah penutupan periode pembukuan (Arens et al, 2011).Pembaharuan kembalidibuat tahun 2012 dengan dikeluarkannya peraturan Kep-431/BL/2012 tentang penyampaian laporan keuangan tahunan emiten atau perusahaan public.

Teori kepatuhan telah diteliti pada ilmu-ilmu sosial khususnya di bidang psikologis dan sosiologi yang lebih menekankan pada pentingnya proses sosialisasi dalam mempengaruhi perilaku kepatuhan seorang individu. Menurut Tyle (2004) terdapat dua perspektif dalam literatur sosiologi mengenai kepatuhan kepada hukum, yang disebut instrumental dan normatif.Perspektif instrumental mengasumsikan individu secara utuh didorong oleh kepentingan pribadi dan tanggapan terhadap perubahan-perubahan yang berhubungan dengan perilaku. Perspektif normatif berhubungan dengan apa yang orang anggap sebagai moral dan berlawanan dengan kepentingan pribadi.Teori kepatuhan dapat mendorong seseorang untuk lebih mematuhi peraturan yang berlaku, sama halnya dengan perusahaan yang berusaha untuk menyampaikan laporan keuangan secara tepat waktu karena selain merupakan suatu kewajiban perusahaan untuk menyampaikan laporan keuangan tepat waktu, juga akan sangat bermanfaat bagi para pengguna laporan keuangan (Sulistyo, 2010).

Proses audit yang dilaksanakan sesuai dengan standar yang berlaku memerlukan waktu yang cukup lama sampai laporan audit ditandatangani dan dipublikasikan. Ketepatwaktuan atas informasi yang terdapat dalam laporan keuangan yang akan dipublikasikan dapat dipengaruhi oleh lamanya rentang waktu antara tanggal laporan audit dengan tanggal tutup buku laporan keuangan. Perbedaan waktu antara tanggal laporan audit dengan tanggal tutup buku laporan keuangan mengindikasikan lamanya pelaksanaan proses audit yang dilakukan oleh auditor (Sunaningsih, 2014). Perbedaan waktu ini disebut dengan audit delay. Audit delay sering juga disebut dengan istilah audit report lag, audit reporting lead time dan durasi audit.

Penelitian-penelitian sebelumnya tentang faktor-faktor yang mempengaruhi audit delay telah dilakukan namun menunjukkan hasil yang tidak konsisten. Penelitian Imelda dan Heri (2007), Kartika (2009), Mantik dan Sujana (2013) menyatakan reputasi KAP berpengaruh pada audit delay, dan penelitian Fitri (2013) menemukan pengaruh negatif ukuran KAP pada penyampaian laporan keuangan. Hasil yang berbeda ditemukan oleh Kartika (2011) dan Febrianty (2011) yang menyatakan bahwa ukuran KAP tidak berpengaruh pada audit delay.Sementara itu, penelitian Kartika (2011) dan Fitri (2013) menyatakan bahwa opini auditor tidak berpengaruh pada audit delay padahal penelitian Kartika (2009) dan Muttaqin (2013) menyatakan bahwa opini auditor berpengaruh pada audit delay. Penelitian-penelitian ini telah membuktikan bahwa terdapat banyak faktor yang dapat mempengaruhi audit delay. Berpijak dari hasil penelitian sebelumnya, maka dapat disimpulkan bahwa terdapat ketidakkonsistenan hasil-hasil penelitian sebelumnya yang mempengaruhi audit delay. Oleh karena itu penelitian ini dilakukan untuk menguji kembali faktor- 
faktor yang mempengaruhi audit delay menggunakan variabel-variabel karakteristik auditor yang diproksikan dengan ukuran perusahaan, jenis opini auditor, ukuran KAP dan audit tenure.

Motivasi penelitian ini adalah pertama karena adanya perbedaan antara hasil penelitian terdahulu mengenai faktor-faktor yang mempengaruhi audit delay yang memberi peluang untuk diteliti kembali. Kedua, pada tiap tahunnya banyak emiten yang masih terlambat melaporkan laporan keuangannya ke Bapepam disebabkan lamanya waktu penyelesaian audit, dan ketiga perusahaan manufaktur memiliki kompleksitas tinggi dibanding jenis perusahaan lain.

\section{TINJAUAN TEORITIS DAN PENGEMBANGAN HIPOTESIS}

\subsection{Teori Kepatuhan (Compliance Theory)}

Teori Kepatuhan (legitimacy theory) dapat diartikan menurut penelitianpenelitian sebelumnya kepatuhan berasal dari kata patuh yang berarti suka menurut perintah, taat kepada perintah atau aturan dan berdisiplin.Patuh dalam kamus ilmiah populer diartikan, sebagai tindakan taat, turut perintah, setia dan loyal akibat motif-motif internal individu. Teori kepatuhan telah diteliti dalam ilmu-ilmu sosial khususnya di bidang psikologi dan sosiologi yang lebih menekankan pada pentingnya proses sosialisasi dalam mempengaruhi perilaku kepatuhan seorang individu.

Tuntutan akan kepatuhan terhadap ketepatan waktu dalam penyampaian laporan keuangan tahunan perusahaan publik di Indonesia telah diatur dalam Undang-Undang Nomor 8 Tahun 1995 tentang "Peraturan Pasar Modal". Berdasarkan peraturan BAPEPAM dan LK, Lampiran Keputusan Ketua BAPEPAM dan LK Nomor KEP-346/BL/2011 tentang Kewajiban Penyampaian Laporan Keuangan Berkala, BAPEPAM dan LK mewajibkan setiap perusahaan publik yang terdaftar di Pasar Modal wajib menyampaikan laporan tahunan yang disertai dengan laporan keuangan auditor independen kepada BAPEPAM dan LK selambat-lambatnya pada akhir bulan ketiga (90 hari) setelah tanggal laporan keuangan tahunan.

Peraturan ini berlaku pada awal tahun 2013.Laporan keuangan juga harus memenuhi empat karakteristik kualitatif yang membuat laporan keuangan berguna bagi pemakainya, yaitu relevance, riable, comparability dan consistency (IAI, 2009).Peraturan-peraturan tersebut secara hukum mengisyaratkan adanya kepatuhan setiap perilaku individu maupun organisasi (perusahaan publik) yang terlibat di pasar modal Indonesia untuk menyampaikan laporan keuangan tahunan perusahaan secara tepat waktu kepada BAPEPAM-LK.

Pemeriksaan terhadap laporan keuangan yang dilakukan oleh auditor independen terhadap suatu perusahaan harus sesuai dengan Standar Profesional Akuntansi Publik (SPAP) yang telah ditetapkan oleh Ikatan Akuntansi Publik Indonesia (IAPI). Pemenuhan standar audit oleh auditor dapat berdampak terhadap lamanya penyelesaian audit, tetapi juga berdampak pada peningkatan kualitas auditnya (Iskandar dan Trisnawati, 2010). 
Dengan berlandaskan peraturan yang diterangkan diatas, melalui teori ini tentunya bertujuan untuk mengajarkan agar seorang agen patuh terhadap prinsipalnya, sehingga agen dapat memenuhi segala pendeglasian prinsipal.Hal tersebut sesuai dengan teori kepatuhan (legitimacy theory). Teori kepatuhan dapat menolong seseorang untuk lebih mematuhi peraturan yang berlaku. Sama halnya dengan perusahaan yang berusaha untuk menyampaikan laporan keuangan secara tepat waktu karena selain merupakan suatu kewajiban perusahaan untuk menyampaikan laporan keuangan tepat waktu, juga akan sangat bermanfaat bagi para pengguna laporan keuangan.

\subsection{Hipotesis Penelitian:}

Ketepatan waktu penerbitan laporan keuangan auditan merupakan hal yang sangat penting khususnya untuk perusahaan-perusahaan publik yang menggunakan pasar modal sebagai salah satu sumber pendanaan. Namun, auditor memerlukan waktu yang cukup lama untuk mengumpulkan bukti-bukti kompeten yang mendukung opininya. Rentang waktu penyelesaian pelaksanaan audit lporan keuangan tahunan, diukur berdasarkan lamanya hari yang dibutuhkan untuk memperoleh laporan auditor independen atas audit laporan keuangan tahunan perusahaan, sejak tanggal tutup tahun buku perusahaan yaitu per 31 Desember sampai tanggal yang tertera pada laporan auditor independen yang didefinisikan sebagai audit delay (Aryati dan Theresia 2005).

\section{$\mathrm{H}_{1} \quad$ Ukuran perusahaan, jenis opini auditor, ukuran KAP dan audit tenure secara simultan berpengaruh positif terhadap audit delay.}

Ukuran perusahaan sebagai salah satu karakteristik perusahaan merupakan faktor yang penting untuk diujikan dalam berbagai penelitian.Terkait dengan ketepatan waktu laporan keuangan tahunan, ukuran perusahaan merupakan fungsi dari kecepatan pelaporan keuangan. Besar kecilnya ukuran perusahaan dipengaruhi oleh beberapa hal, diantaranya adalah kompleksitas operasional, variabilitas dan intensitas transaksi perusahaan tersebut yang tentunya akan berpengaruh terhadap kecepatan dalam menyajikan laporan keungan kepada publik.Boyton et.al (2002) berpendapat "audit delay akan semakin lama apabila ukuran perusahaan yang akan diaudit semakin besar". Hal ini berkaitan dengan semakin banyaknya jumlah sampel yang harus diambil dan semakin luasnya prosedur yang harus dilakukan auditor.

\section{$\mathrm{H}_{2}$ Ukuran perusahaan berpengaruh secara positif terhadap audit delay.}

Opini selain wajar tanpa pengecualian merupakan opini yang tidak diharapkan oleh semua manajemen. Semakin tidak baik opini yang diterima oleh perusahaan maka semakin lama laporan keuangan audit dipublikasikan. Laporan keuangan yang disampaikan tidak tepat waktu mencerminkan ketidakpatuhan perusahaan terhadap peraturan yang ada. Hasil penelitian Bestian (2010) menemukan adanya pengaruh opini auditor terhadap audit delay. Pada perusahaan yang menerima pendapat selain wajar tanpa pengecualian akan menunjukan audit delay yang lebih panjang dibandingkan dengan perusahaan yang menerima pendapat wajar tanpa pengecualian.

$\mathrm{H}_{3}$ Jenis opini auditor berpengaruh secara positif terhadap audit delay. 
Ukuran Kantor Akuntan Publik diantaranya dapat diukur berdasarkan jumlah karyawan, jumlah klien, serta reputasi. Kantor Akuntan Publik besar memiliki jumlah yang karyawan yang banyak, dapat mengaudit dengan lebih efisien dan efektif, memiliki jadwal yang fleksibel sehingga memungkinkan untuk menyelesaikan audit tepat waktu, serta memiliki dorongan yang lebih kuat untuk menyelesaikan auditnya lebih cepat guna menjaga reputasinya. Ukuran KAP berdasarkan jumlah partner pada suatu KAP, yang terbagi atas KAP besar, menengah dan kecil. Wibowo \& Rossieta (2009) menunjukan KAP besar memiliki kualitas audit yang lebih tinggi daripada KAP menengah dan kecil.

\section{$\mathrm{H}_{4} \quad$ Ukuran KAP berpengaruh secara positif terhadap audit delay.}

Berdasarkan penelitian terdahulu mengenai pengaruh audit tenure terhadap audit delay menghasilkan perbedaan penelitian. Menutur lee et al (2009) mengargumentasikan bahwa variabel audit tenure yang lebih panjang akan semakin meningkatkan efesiensi audit. Pnelitian ini mengindikasikan bahwa semakin panjang tenure audit mengakibatkan auditor akan semakin banyak memiliki pengalaman dan pengetahuan mengenai karakteristik klien serta operasional bisnis kliennya. Hal ini akan menciptakan efisiensi yang semakin meningkat sehingga waktu yang dibutuhkan dalam penyelesaian audit atas laporan keuangan akan semakin lebih cepat diselesaikan dengan kata lain audit delay semakin pendek.

\section{$\mathrm{H}_{5}$ Audit tenure berpengaruh secara positif terhadap audit delay.}

\section{METODE PENELITIAN}

\subsection{Pemilihan Sampel dan Pengumpulan Data}

Objek penelitian ini adalah seluruh perusahaan manufaktur yang terdaftar di Bursa Efek Indonesia (BEI) pada tahun 2010-2014. Sampel dalam penelitian ini dipilih dengan metode purposive sampling. Jumlah sampel dalam penelitian ini adalah sebanyak 90 perussahaan untuk masing-masing periode. Jumlah dta dalam penelitian ini adalah sebanyak 450 perusahaan. Berikut proses pemilihan sampel:

Tabel 3.1 Kriteria Pemilihan Sampel

\begin{tabular}{clc}
\hline NO & \multicolumn{1}{c}{ Kriteria } & Jumlah \\
\hline 1 & Perusahaan manufaktur terdaftar di BEI pada periode 2010-2014 & 144 \\
2 & Perusahaan yang deslisting dan baru IPO pada periode 2010-2014 & $(19)$ \\
3 & $\begin{array}{l}\text { Perusahaan yang menerbitkan laporan keuangan tahunan yang } \\
\text { dinyatakan tidak dalam rupiah pada periode 2010-2014 }\end{array}$ & $(27)$ \\
4 & Perusahaan yang tidaklegkap mempublikasikan laporan tahunan & \\
& secara rutin selama 5 tahun pada periode 2010-2014 & $(8)$ \\
5 & Jumlah perusahaan yang menjadi sampel & 90 \\
6 & Jumlah periode penelitian & 5 \\
7 & Jumlah sampel selama periode penelitian & 450 \\
\hline
\end{tabular}


Penelitian ini menggunakan sumber data sekunder berupa laporan auditor independen. Data yang digunakan dalam penelitian ini bersumber dari www.idx.co.id.

\subsection{Definisi Operasionalisasi dan Pengukuran Variabel}

Variabel independen yang digunakan dalam penelitian ini adalah ukuran perusahaan, jenis opini auditor, ukuran KAP dan audit tenure. Variabel dependen dalam penelitian ini adalah audit delay. Definisi operasional dan pengukuran variabel dalam penelitian ini dapat dijelaskan sebagai berikut:

Tabel 2 Definisi Operasional dan Pengukuran Variabel

\begin{tabular}{|c|c|c|c|c|}
\hline No & Variabel & Konsep Variabel & Rumus & Skala \\
\hline 1. & Audit Delay & $\begin{array}{l}\text { Lamanya rentang waktu } \\
\text { penyelesaian audit }\end{array}$ & $\begin{array}{l}\text { Tanggal penutupan } \\
\text { tahun buku hingga } \\
\text { tanggal } \\
\text { ditandatanganinya } \\
\text { laporan audit (tangga } \\
\text { opini) }\end{array}$ & Lanjutan Tabel 2 \\
\hline 2. & $\begin{array}{l}\text { Ukuran } \\
\text { Perusahaan }\end{array}$ & $\begin{array}{l}\text { Total aset yang dimiliki } \\
\text { emiten pada tahun } \\
\text { pelaporan }\end{array}$ & Ln Total Aset & Rasio \\
\hline 3. & $\begin{array}{l}\text { Jenis Opini } \\
\text { Auditor }\end{array}$ & $\begin{array}{l}\text { Pendapat } \\
\text { diberikan } \\
\text { kewajaran } \\
\text { keuangan }\end{array}$ & $\begin{array}{l}\text { '1' perusahaan yang } \\
\text { mendapatkan opini } \\
\text { wajar tanpa } \\
\text { pengecualian dan } \\
\text { '0'selain wajar tanpa } \\
\text { pengecualian. }\end{array}$ & $\begin{array}{l}\text { Nominal } \\
\text { dengan } \\
\text { Dummy }\end{array}$ \\
\hline 4. & $\begin{array}{l}\text { Ukuran } \\
\text { KAP }\end{array}$ & Jumlah partner KAP & Total Partner & Interval \\
\hline 5. & $\begin{array}{l}\text { Audit } \\
\text { Tenure }\end{array}$ & $\begin{array}{l}\text { Lama perikatan KAP } \\
\text { dalam memberikan jasa } \\
\text { audit kepada kliennya }\end{array}$ & $\begin{array}{l}\text { ' } 1 \text { ' diaudit KAP yang } \\
\text { sama > } 5 \text { tahun dan '0' } \\
\text { diaudit KAP yang sam. } \\
<5 \text { tahun. }\end{array}$ & $\begin{array}{l}\text { Nominal } \\
\text { dengan } \\
\text { Dummy }\end{array}$ \\
\hline
\end{tabular}

\section{HASIL PENELITIAN}

\subsection{Statistik Deskrptif}

Tabel 4.1 Statistik Deskriptif

\begin{tabular}{lrrrrr}
\hline & $\mathrm{N}$ & Minimum & Maximum & Mean & $\begin{array}{c}\text { Std. } \\
\text { Deviation }\end{array}$ \\
\hline DELAY & 450 & 31,00 & 149,00 & 78,2511 & 15,39912 \\
SIZE & 450 & 1058284235 & 23602900000000 & 63382672561 & 2,12694 \\
OPINI & 450 & 9 & 0 & 35 &, 14016
\end{tabular}




\begin{tabular}{lrrrrr} 
KAP & 450 & 1,00 & 35,00 & 16,7333 & 8,76620 \\
TENURE & 450 &, 00 & 1,00 &, 5778 &, 49446 \\
$\begin{array}{l}\text { Valid N } \\
\text { (listwise) }\end{array}$ & 450 & & & & \\
\hline
\end{tabular}

Berdasarkan tabel diatas, terlihat bahwa rata-rata jumlah hari audit delay adalah 78,2511 dengan standar deviasi sebesar 15,39912. Jumlah hari audit delay yang tercepat adalah 31 hari yang dilakukan oleh PT. Holcim Indonesia Tbk pada tahun 2010, sedangkan jumlah hari audit delay yang terlama adalah 149 hari yang dilakukan olehPT. Sunson Textile Manufacturer Tbk pada tahun 2011. Dari 90 hari waktu yang ditentukan oleh BAPEPAM untuk penyampaian laporan keuangan, rata-rata lamanya waktu penyampaian keuangan perusahaan manufaktur adalah 78 hari, yang menunjukan bahwa perusahaan manufaktur ratarata tidak mengalami keterlambatan dalam penyampaian laporan keuangan.

Ukuran perusahaan dilihat dari total aset perusahaan yang memiliki rata-rata sebesar Rp. 6.338.267.256.135,- dengan standar deviasi sebesar 2,12694. Size yang terkecil dicapai oleh PT. Alam Karya Unggul Tbk sebesar Rp. 10.582.842.359,- yaitu pada tahun 2012, sedangkan nilai terbesar size dicapai oleh PT Astra International Tbk sebesar Rp. 236.029.000.000.000,- pada tahun 2014. Dengan demikian rata-rata total aset sebesar Rp. 6.338.267.256.135,-, dapat dikatakan bahwa perusahaan yang ada di Indonesia terdistribusi dalam berbagai ukuran kecil, menengah hingga besar. Rata-rata aset perusahaan menunjukan bahwa didominasi dengan perusahaan besar.

Opini audit memiliki nilai minimum 0, dan nilai maksimum 1. Nilai ratarata untuk variabel opini audit sebesar 0,98 dan standar deviasi 0,14016. Nilai rata-rata diatas menunjukan bahwa sebesar $98 \%$ perusahaan manufaktur mendapatkan pendapat wajar tanpa pengecualian, sedangkan $2 \%$ sisanya mendapat pendapat selain wajar tanpa pengecualian.

Variabel ukuran KAP dilihat dari jumlah partner. Nilai rata-rata untuk variabel ukuran KAP sebsar 16,7333 dan standar deviasinya 8,76620. Untuk mengetahui kategori ukuran KAP, maka menggunakan tabel distribusi frekuensi menunjukan bahwa sebesar 16,7333 masuk kategori ukuran sedang, yang artinya perusahaan manufaktur rata-rata menggunakan jasa Kantor Akuntan Publik dengan jumlah partner 16 partner.

Audit tenure memiliki nilai minimum 0 dan nilai maksimum 1 . Nilai ratarata untuk variabel audit tenure sebesar 0,5778 dan standar deviasinya 0,49446. Nilai rata-rata diatas menunjukan bahwa sebesar $57,78 \%$ perusahaan manufaktur tidak mengganti Kantor Akuntan Publik selama 5 tahun, sedangkan 42,22\% mengganti Kantor Akuntan Publik. 


\subsection{Uji Normalitas}

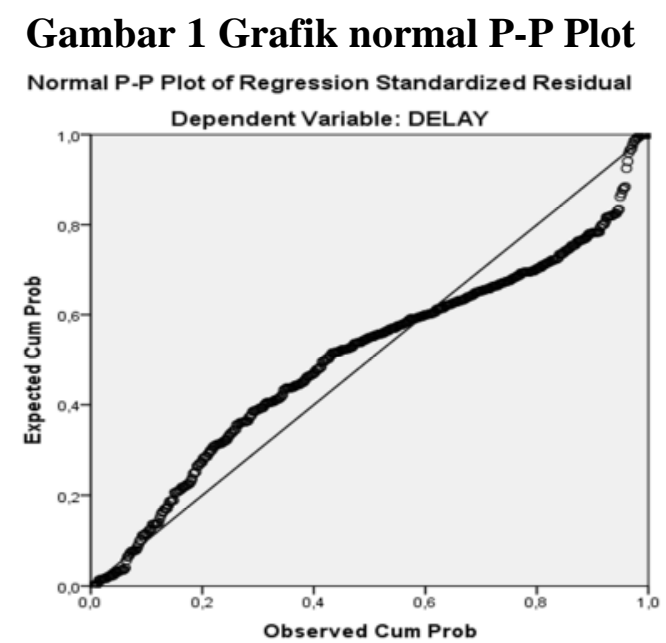

Titik-titik sebaran data menyebar disekeliling garis lurus, maka dapat dikatakan model regresi memenuhi persyaratan normalitas.

\subsection{Uji Multikolinearitas}

Nilai VIF dari variabel ukuran perusahaan $(1,241)$, jenis opini auditor $(1,004)$, ukuran KAP $(1,357)$, dan audit tenure $(1,222)$. untuk keempat variabel masih jauh dibawah nilai 10 . Sedangkan nilai tolerance menunjukan angka lebih besar dari $10 \%$ atau 0,10 pada keempat variabel independen, ukuran perusahaan $(0,806)$, jenis opini auditor $(0,996)$, ukuran $\operatorname{KAP}(0,737)$, dan audit tenure $(0,819)$. Sehingga dapat disimpulkan model regresi ini telah memenuhi syarat multikolinearitas.

Tabel 4 Uji Multikolinearitas

\begin{tabular}{|c|c|c|c|}
\hline & \multicolumn{3}{|c|}{ Coefficients $^{\mathrm{a}}$} \\
\hline \multirow{2}{*}{\multicolumn{2}{|c|}{ Model }} & \multicolumn{2}{|c|}{ Collinearity Statistics } \\
\hline & & Tolerance & VIF \\
\hline \multicolumn{4}{|c|}{ (Constant) } \\
\hline \multirow{4}{*}{1} & SIZE & ,806 & 1,241 \\
\hline & OPINI & ,996 & 1,004 \\
\hline & KAP & ,737 & 1,357 \\
\hline & TENURE & ,819 & 1,222 \\
\hline
\end{tabular}




\subsection{Uji Autokorelasi}

Tabel 5 Uji Autokorelasi

Model Summary ${ }^{b}$

\begin{tabular}{|l|r|r|r|r|r|}
\hline $\begin{array}{l}\text { Mode } \\
1\end{array}$ & $\mathrm{R}$ & $\mathrm{R}$ Square & $\begin{array}{c}\text { Adjusted R } \\
\text { Square }\end{array}$ & $\begin{array}{c}\text { Std. Error of } \\
\text { the Estimate }\end{array}$ & $\begin{array}{c}\text { Durbin- } \\
\text { Watson }\end{array}$ \\
\hline 1 &, $256^{\mathrm{a}}$ &, 066 &, 057 & 14,95253 & 1,876 \\
\hline
\end{tabular}

Diperoleh nilai Durbin-Watson berada pada dU < DW < 4-dU atau 1,858 $<1,867<2,141$. Hal tersebut menunjukan bahwa tidak terjadi autokorelasi antar kesalahan pengganggu.

\subsection{Uji Heteroskedastisitas}

\section{Gambar 2 Uji Heteroskedastisitas}

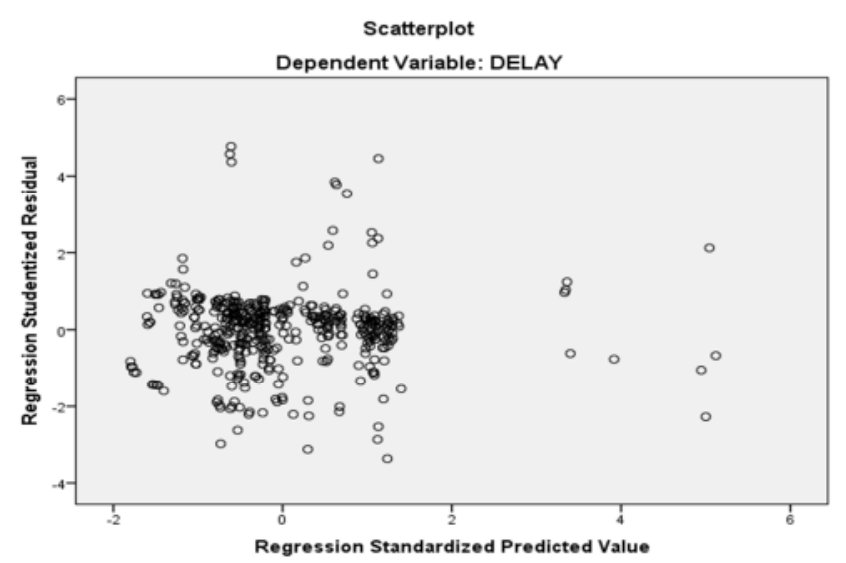

Grafik scatterplot terlihat bahwa titik-titik menyebar secara acak serta tersebar baik di atas maupun di bawah angka 0 pada sumbu Y. Hal ini dapat disimpulkan bahwa tidak terjadi heteroskedastisitas pada model regresi.

\subsection{Pengujian Hipotesis}

Hasil pengujian hipotesis dapat dilihat:

Tabel 4 Hasil Pengujian Hipotesis

\begin{tabular}{lrr}
\hline \multicolumn{1}{c}{ Variabel } & \multicolumn{1}{c}{ B } & \multicolumn{1}{c}{ Sig. } \\
\hline Konstanta & 108,716 &, 000 \\
SIZE &,- 366 &, 438 \\
OPINI & $-15,411$ &, 002 \\
KAP &,- 180 &, 055 \\
TENURE & $-3,722$ &, 019 \\
\hline
\end{tabular}




\section{$\mathrm{H}_{1}$ : Ukuran perusahaan, jenis opini auditor, ukuran KAP dan audit tenure} secara simultan berpengaruh positif terhadap audit delay

Berdasarkan hasil penelitian diperoleh bahwa Ukuran perusahaan, jenis opini auditor, ukuran KAP dan audit tenure secara simultan berpengaruh terhadap audit delay dengan signifikansi sebesar 0,000. Hasil ini sesuai dengan $\mathrm{H}_{1}$ bahwa ukuran perusahaan,jenis opini auditor, ukuran KAP dan audit tenure secara simultan berpengaruh positif terhadap audit delay sehingga $\mathrm{H}_{1}$ diterima.

Hal ini mengindikasikan apabila besar, sedang dan kecilnya ukuran perusahaan akan mempengaruhi panjang pendeknya audit delay. Perusahaan yang mengeluarkan opini audit positif dari seorang auditor akan lebih dipercaya oleh para investor karena laporan keuangan tersebut menandakan kewajaran perusahaan menyampaikan informasi, posisi keuangan dan kinerja perusahaan. Bahwa semakin baik kredibilitas yang dimiliki suatu KAP maka proses audit yang dilakukan oleh perusahaan lebih singkat dan semakin lama masa jabatan dari KAP dalam memberikan jasanya memungkinkan auditor mengenali industri klien akan memperpendek masa penyelesaian, sehingga penyampaian laporan keuangannya akan tepat waktu. Dengan demikian, hasil penelitian tersebut bahwa panjang pendeknya waktu proses audit dipengaruhi oleh ukuran KAP, jenis opini auditor, Ukuran KAP dan audit tenure.

\section{$\mathrm{H}_{2}$ : Ukuran perusahaan tidak berpengaruh secara negatif terhadap audit delay \\ Diperoleh sebesar -0,366 dengan nilai signifikansi menunjukan angka} 0,438 . Hal ini menunjukan bahwa variabel ukuran perusahaan tidak berpengaruh secara negatif terhadap audit delay, sehingga $\mathrm{H}_{2}$ ditolak.

Tidak berpengaruh terhadap audit delay karena sampel merupakan perusahaan terdaftar di BEI yang diawasi oleh investor, pengawas permodalan, dan pemerintah. Atas dasar itu, perusahaan dengan aset besar, sedang maupun kecil mempunyai kemungkinan yang sama dalam menghadapi tekanan atas penyampaian laporan keuangan.

Hasil tersebut sejalan dengan penelitian destiana (2011), lianto dan kusuma (2010) bahwa ukuran perusahaan tidak mempunyai pengaruh yang signifikan terhadap audit delay.

\section{$\mathrm{H}_{3}$ : Jenis opini auditor berpengaruhsecara negatif terhadap audit delay}

Diperoleh sebesar -15,411 dengan nilai signifikansi menunjukan angka 0,002. Hal ini menunjukan bahwa variabel jenis opini auditor berpengaruh secara negatif terhadap audit delay, sehingga $\mathrm{H}_{3}$ diterima.

Variabel opini audit dianggap berpengaruh signifikan terhadap audit delay karena perusahaan yang mendapatkan opini selain wajar tanpa pengecualian akan mematuhi aturan OJK (Otoritas Jasa Keuangan) untuk tidak delay yang diamanahkan oleh regulator tersebut. Pendapat auditor sangatlah penting bagi perusahaan ataupun pihak-pihak lain yang membutuhkan hasil dari laporan keuangan auditan. Auditor dapat memilih tipe pendapat yang akan dinyatakan atas laporan keuangan auditan bedasarkan bukti dan penemuan selama melaksanakan 
pekerjaan lapangan, karena pengguna memakai untuk pengambilan keputusan untuk tepat waktu.

Hasil dari penelitian ini menunjukan bahwa perusahaan yang menerima selain opini wajar tanpa pengecualian akan mengalami audit delay yang relatif lebih lama, karena proses pemberian opini audit melibatkan negosiasi dengan klien konsultasi dengan rekan auditor yang lebih senior atau staf teknis lainnya dan perluasan lingkup audit.

Hal ini sejalan dengan penelitian destiana (2011), Arifa (2013), Saputri (2012) yang menyatakan bahwa jenis opini auditor memiliki pengaruh yang signifikan terhadap audit delay.

\section{$\mathrm{H}_{4}$ : Ukuran KAP tidak berpengaruh secara negatifterhadap audit delay}

Diperoleh sebesar -0,180 dengan nilai signifikansi menunjukan angka 0,055 . Hal ini menunjukan bahwa variabel ukuran KAP tidak berpengaruh secara negatif terhadap audit delay, sehingga $\mathrm{H}_{4}$ ditolak.

Hal ini menjelaskan bahwa perusahaan yang diaudit oleh KAP besar, sedang maupun kecil tidak berpengaruh pada audit delay dikarenakan setiap perusahaan yang diperiksa dengan cara yang sama, sesuai dengan standar profesional akuntan publik untuk mematuhi dalam standar pemeriksaan serta pelaporan.

Hasil penelitian ini mendukung penelitian yang dilakukan oleh Wulansari \& Supriyanti (2012) dan Laksono \& Muid (2014) yang menyatakan bahwa ukuran kap tidak berpengaruh terhadap audit delay.

\section{$\mathrm{H}_{5}$ : Audit tenure berpengaruh secara negatif terhadap audit delay}

Diperoleh sebesar -3,722 diatas menunjukkan bahwa nilai signifikansi menunjukan angka 0,019 atau lebih kecil dari 0,05. Hal ini menunjukan bahwa variabel jenis opini auditor berpengaruh secara negatif terhadap audit delay, sehingga $\mathrm{H}_{5}$ diterima.

Lama masa jabatan KAP mempengaruhi audit delay dikarenakan pemahaman atas karakteristik bisnis klien, dengan tenure yang panjang diharapkan memiliki pemahaman dan pengetahuan atas karakteristik bisnis industri perusahaan klien, sehingga dapat mengurangi potensi kegagalan audit dan meningkatkan efisiensi audit, yang kemudian menghasilkan audit delay semakin pendek. Hasil penelitian menunjukan bahwa KAP dengan tenure selama lebih dari atau sama dengan 5 tahun menghasilkan audit delay yang lebih panjang dibandingkan KAP dengan tenure kurang dari 5 tahun menandakan bahwa proses akumulasi pemahaman dan pengetahuan atas kondisi dan sistem akuntansi klien tidak berjalan dengan efektif dan progresif. Hal ini mungkin disebabkan bahwa KAP dengan tenure pendek, masih menilai bahwa dalam mengaudit laporan keuangan klien, auditor masih membutuhkan pembelajaran dalam beradaptasi dengan karakteristik bisnis dan sistem pencatatan klien, sehingga proses pemahaman dilakukan dengan optimal. Sedangkan KAP yang memiliki tenure panjang diduga menilai bahwa KAP telah memiliki pengetahuan yang cukup dihasilkan dari perikatan audit dengan klien yang sudah berjalan relatif lama. Hal 
ini mengakibatkan proses pemahaman akumulatif KAP atas klien menurun pada tahun ke-5 dan seterusnya.

Hasil penelitian tersebut sesuai dengan penelitian yang dilakukan oleh Rustiarini dan Mita (2013) yang menyatakan bahwa variabel pergantian auditor mempunyai pengaruh signifikan terhadap audit delay.

\section{KESIMPULAN DAN SARAN}

Berdasarkan hasil penelitian yang telah dilakukan, maka dapat ditarik simpulan bahwa ukuran perusahaan, jenis opini auditor, ukuran KAP dan audit tenure secara simultan berpengaruh positif terhadap audit delay, ukuran perusahaan tidak berpengaruh secara negatif terhadap audit delay, jenis opini auditor berpengaruh secara negatif terhadap audit delay, ukuran KAP tidak berpengaruh secara negatif terhadap audit delay, audit tenure berpengaruh secara negatif terhadap audit delay.

Penelitian ini hanya menggunakan 4 variabel independen dan dengan melihat nilai adjusted $R^{2}$ yang rendah yaitu 0,057 , maka hal ini menunjukan masih terdapat variabel independen lain yang mempengaruhi audit delay. Penelitin selanjutnya dapat menambahkan variabel independen lain seperti profitabilitas, solvabilitas, umur perusahaan dan besarnya audit fee.

\section{DAFTAR PUSTAKA}

Sekaran, Uma. (2016). Metodologi Penelitian untuk Bisnis, Edisi 4, Buku 1, Jakarta: Salemba Empat.

Sekaran, Uma. (2016). Metodologi Penelitian untuk Bisnis, Edisi 4, Buku 2, Jakarta: Salemba Empat.

Ghozali, Imam. (2016). Aplikasi Analisis Multivariate dengan Program IBM SPSS. Semarang: BP UNDIP.

Agoes, Sukrisno. (2014). Auditing (PemeriksaanAkuntan) oleh Kantor AkuntanPublik. Jakarta: Lembaga Penerbit Fakultas Ekonomi Universitas Indonesia

Trianto, Imam et al. (2014). Analisis faktor-faktor yang mempengaruhi audit delay (studi empiris pada Perusahaan Pertambangan yang terdaftar di Bursa Efek Indonesia). Jom FEKON. (Volume 1; No. 2)

IkatanAkuntan Indonesia. (2012). StandarProfesionalAkuntanPublik. Jakarta

IkatanAkuntan Indonesia. (2012). Standar Akuntansi Keuangan. Jakarta

Priyantno, Duwi. (2012). Cara Kilat Belajar Analisis Data dengan SPSS20. Yogyakarta: Andi Offset.

Puspitasari Dan Sari. (2012). Pengaruh Karakteristik Perusahaan Terhadap Lamanya Waktu Penyelesaian Audit (Audit Delay). Jurnal Akuntansi dan Auditing (Vol 9, No 1, November: 1-96). 
Arens A. Alvin, dkk. (2011). Auditing danJasa Assurance pendekatanterintegrasi. Jakarta: Erlangga

BAPEPAM. (2011). Keputusan Ketua Badan Pengawas Pasar Modal No.Kep346/BL/2011 (Peraturan Nomor X.K.2) tentang Penyampaian Laporan Keuangan Berkala Emiten atau Perusahaan Publik

Kartika, Andi. (2011). Faktor-faktor yang mempengaruhi audit delay pada Perusahaan Manufaktur yang terdaftar di BEI. Dinamika Keuangan dan Perbankan. (Volume 3; No. 1)

Pernyataan Standar Auditing no 29. (2011). Standar Auditing seksi 508. Standar Profesional Akuntansi Publik (SPAP). Jakarta: Salemba.

Mulyadi. (2008). Auditing edisi 6. Yogyakarta: Salemba Empat

Boynton, Johnson Kell. (2003). Modern Auditing EdisikeTujuh. Jakarta: Erlanggga

Messier, William F Jr. Steven M. Glover, dan Douglas F Prawit.Auditing and Assurance Service BukuSatu (EdisiEmpat). (2005). Jakarta: SalembaEmpat

Sugiyono.(2010). MetodologiPenelitianBisnis. Bandung: Alfabeta Bandung Munawir. (2007). AnalisaLaporanKeuangan. Yogyakarta: Liberti Yogyakarta Margono. (2010). MetodologiPenelitianPendidikan. Jakarta: RinekaCipta Bastian Indra. (2007). AkuntansiYayasandanLembagaPublik. Jakarta: Erlangga Sarwono, Jonathan. (2006). Metode Penelitian Kuantitatif dan Kualitatif. Yogyakarta: Graha Ilmu

Sukmana, Ahmad. (2010). MetodologiRiset (Modul Perkuliahan). Pamulang: Fakultas Ekonomi Universitas Pamulang

IAPI. (2010). Directory 2010 Kantor Akuntan Publik dan Akuntan Publik. Jakarta IAPI. (2011). Directory 2011 Kantor Akuntan Publik dan Akuntan Publik. Jakarta IAPI. (2012). Directory 2012 Kantor Akuntan Publik dan Akuntan Publik. Jakarta IAPI. (2013). Directory 2013 Kantor Akuntan Publik dan Akuntan Publik. Jakarta IAPI. (2014). Directory 2014 Kantor Akuntan Publik dan Akuntan Publik. Jakarta IAPI. (2015). Directory 2015 Kantor Akuntan Publik dan Akuntan Publik. Jakarta https://idx.co.id

https://sahamok.com

https://sikap.bpk.go.id 